\title{
Designing an industrial protocol to develop a new fat-reduced-ice cream formulation by replacing stabilizers with microbial transglutaminase enzyme
}

\author{
M. Serdar Akin*, Busra Goncu, Mutlu B. Akin \\ Harran University Agricultural Faculty, Department of Food Engineering, Sanliurfa, Turkey, 63100 \\ ${ }^{*}$ Corresponding author: E-mail: mutluakin@harran.edu.tr
}

\section{Abstract}

In this study, the possibility of replacing stabilizers with microbial transglutaminase (MTG) enzyme in fat-reduced ice cream production was studied. In addition, the stage of adding (before or after the heat treatment) the MTG enzyme to ice cream was also investigated. Five different ice creams ( $A$ and C containing 1 unit MTG/g protein without stabilizer, B and D containing 0.5 unit MTG/g protein and $0.35 \%$ stabilizer, which also consist of the mixture of Carrageenan (E 407), Guar gum (E 412), Xanthan gum (E 415) and Sodium alginate (E 401), and E (control) containing $0.7 \%$ stabilizer) were manufactured. MTG has been added to samples $A$ and $B$ after heat treatment while it was added to $C$ and $D$ samples before the heat treatment. An experimental analysis related to the overrun, viscosity melting properties, $\mathrm{pH}$, titratable acidity, dry matter, fat, protein, sensorial and microstructural properties of ice creams was carried out. According to the results, the amount and the adding stage of MTG significantly affected overrun, melting, viscosity, coldness, firmness, smoothness, mouth coating, color, appearance, taste, smell scores, and also microstructure of ice creams $(p<0.01)$. Results also showed that MTG could be used together with other stabilizers after heat treatment in the production of ice cream. Moreover, our findings demonstrated that sample B was the closest to control in terms of sensorial properties.

\section{Key words: fat-reduced ice cream, transglutaminase, stability, quality, microstructure}

\section{Introduction}

Ice creams are complex colloidal systems which, in the frozen state, comprise of ice crystals, air bubbles, partially-coalesced fat globules and aggregates, all in discrete phases surrounded by an unfrozen continuous matrix of sugars, proteins, salts, polysaccharides, and water (Goff, 2002). Ice cream contains a high concentration of fat (Metwally, 2007), which is considered as a multifunctional ingredient and influences the creaminess
(Koxholt et al., 2001), texture, mouthfeel (Adapa et al., 2000), colour and flavour of these products (Gonzalez-Tomas et. al., 2008). Fat also contributes to the ice cream properties of during freezing and beating, especially through the formation of a three-dimensional network of partially-coalesced fat globules. Some of the fat globules surround air bubbles, which results in stabilizing the air phase and increasing levels of fat aggregation, thus improving the melting resistance (Granger et al., 2005) and ice recrystallization (Goff, 2002). 
Stabilizers are other ice cream constituents that partially increase mix viscosity, improve the product aeration and body, restrict ice-crystal growth during storage, control the rate of meltdown and prevent shrinkage of product volume during storage. The increased concentration of stabilizers leads to a non- linear increase in the apparent viscosity of mix (Cottrell et al., 1980). Besides fat and stabilizer, mix proteins also affect mix viscosity and foaming ability (Cottrell et al., 1980). Milk proteins, present in ice cream formulations, emulsify the fat and contribute to partial coalescence and fat structure formation. They are adsorbed at the air interface, leading to enhanced aeration and foam stability. On the other hand, the proteins, not present at interfaces, contribute to enhancing the viscosity and textural quality of the ice cream (Vega and Goff, 2005).

The formation of ice cream structure is hindered when the fat content is reduced and certain quality attributes such as viscosity, ice crystallization, hardness, melting rate, and flavor, are also affected (El-Nagar et al., 2002). Fat components are often replaced by carbohydrates and proteins which can perform same functional properties (Benjamins et al., 2009). The enzyme transglutaminase (TG), which is Generally Recognized As Safe (GRAS) by the Food and Drug Administration (FDA, 2010), has a high affinity for dairy proteins and modifies their functional properties.

Microbial transglutaminase (MTG) (EC 2.3.2.13), which is obtained from Streptoverticillium S-8112 strain, catalyzes an acyl transfer reaction between c- carboxy amide groups of peptide bound glutamine residues (acyl donor) and primary amino groups in a variety of amine compounds (acyl acceptor) such as the peptide bound $\varepsilon$-(g-glutamyl)amino groups of lysine (Kieliszek and Misiewicz, 2014; Soleymanpuori et al., 2014). The enzyme catalyzes protein cross-linking, protein deamination and amine incorporation. However, cross-linking dominates the first 30 min of reaction. Caseins are good substrates for the enzyme action (de Goes-Favoni and Bueno 2014; Sanli et al., 2014), particularly after heating. Beta-lactoglobulin, on the other hand, requires heating so that the enzyme can react with it (Sharma et al., 2001). TG treatment of milk proteins modifies their functional properties such as solubility and hydration ability, rheological and emul- sifying properties and improve protein heat stability. It has been suggested that various dairy products like yoghurt with reduced fat and protein could be produced by TG having the texture similar to the full fat and high total solid products (Faergemand et al., 1999; Kasprzyk et al., 2016; Romeih and Walker, 2017). In other words, the action of TG could simulate fat in fermented milk products and could replace fat substitutes in low-fat products (Lorenzen et al., 2002; Hinz et al., 2012; Jooyandeh et al., 2017). Therefore, considering the fact that the demand for low-fat dairy products is increasing (Romeih and Walker, 2017; Gharibzahedi et al., 2018a, b; Garibzahedi and Chronakis, 2018), TG is regarded to be of great importance in food engineering applications.

On the other hand, ice cream is one of the highfat dairy products (approximately $10 \%$ fat) and its fat content needs to be reduced; however, the reduction of ice-cream fat contents would adversely affect the product's physical and sensory properties (El Nagar et al., 2002). Stabilizers are one of the ingredients that control ice-cream's physical structure. But, they are sometimes expensive and their percentages in ice cream are difficult to be reduced (Lal et al., 2006).

Studies have shown that MTG enzyme improves the textural properties of low-fat ice cream and increases melting resistancy and stability of it (Metwally, 2007; Rossa et al., 2011; 2012; Kafshgari et al., 2014; 2017; Kasprzyk et al., 2016). However, there is no study on the use of MTG enzyme as a stabilizer in ice cream production.

In these contexts, the aim of this study is to reduce the amount of stabilizer in low-fat ice cream and to produce ice-cream with same properties by replacing regular level stabilizer by adding MTC enzyme. For this purpose, five different ice cream samples containing MTG enzyme with or without stabilizer were manufactured ( $A$ and $C$ containing 1 unit MTG/g protein without stabilizer, as suggested by producer, $B$ and D containing 0.5 unit MTG /g protein and $0.35 \%$ stabilizer, as determined in pre-trials, and E (control) containing $0.7 \%$ stabilizer, as determined in pre-trials. MTG enzyme was added to these ice cream mixes before and after heat treatment ( $A$ and $B$ samples were treated with MTG enzyme after heat treatment while $C$ and D samples were treated with MTG enzyme before 
heat treatment). Then, the effects of the added amount and the stage of adding MTG enzyme on the physical, microstructural and sensory properties of ice creams were investigated.

\section{Materials and methods}

\section{Materials}

Nonfat milk powder (96\% total solids) (Pınar Dairy, Turkey) and cream (35\% fat) (Tat Can Industry. A.S. SEK Plant, Turkey) were used for ice cream production. Carrageenan (E 407), Guar gum (E 412), Xanthan gum (E 415) and Sodium alginate (E 401) (Sosa Ingredients, S.L. Ctra de Granera, Spain) were used as stabilizers. Lecithin was used as an emulsifier and obtained from Sosa Ingredients (S.L. Ctra de Granera, Spain). Sucrose (100 \% TS) was used as a sweetener, and vanilla was added for giving aroma. MTG was recieved as a gift from Activa, Ajinomoto Co. Inc. (Japan). The declared activity of the preparation was approximately $1000 \mathrm{U} \mathrm{g}^{-1}$.

\section{Ice cream production}

The ice cream was formulated with the following composition (percentage by weight): $32-33 \%$ of total solids for a total batch of $5 \mathrm{~kg}, 10 \%$ nonfat total milk solids, $18 \%$ sugar, $4 \%$ fat, and $0.3 \%$ emulsifier. The amount of stabilizers and MTG are listed in Table 1.

TABLE 1. The stabilizers and MTG enzyme amounts in ice cream samples

\begin{tabular}{|c|c|c|c|c|c|}
\hline Stabilizers & 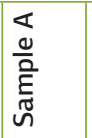 &  & $\begin{array}{l}\cup \\
\frac{0}{0} \\
\text { है } \\
\text { ज̃ }\end{array}$ & 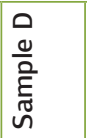 & 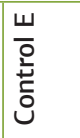 \\
\hline Lecithin (\%) & 0.3 & 0.3 & 0.3 & 0.3 & 0.3 \\
\hline Guar gum (\%) & - & 0.1 & - & 0.1 & 0.2 \\
\hline Carrageenan (\%) & - & 0.1 & - & 0.1 & 0.2 \\
\hline Xanthan gum (\%) & - & 0.1 & - & 0.1 & 0.2 \\
\hline Na-Alginate (\%) & - & 0.05 & - & 0.05 & 0.1 \\
\hline $\begin{array}{l}\text { MTG } \\
\text { (unit enzyme } \\
\text { /g protein) }\end{array}$ & 1 & 0.5 & 1 & 0.5 & - \\
\hline
\end{tabular}

Five different mixes were prepared from the above listed ingredients with same calculations except for MTG addition. Ice cream mixes were treated with MTG in two different manufacturing stages. While the first treatment was prior to pasteurization of the mixture, the second treatment was after it. The first (A) and the third (C) batches contain 1 unit of MTG/g protein wheras the second (B) and the fourth (D) batches contain 0.5 unit of MTG /g protein+0.35\% stabilizer, respectively. The fifth batch was the control (E) which contains $0.7 \%$ stabilizer mixtures. The batches A, B and E were pasteurized in a jacked boiler at $85^{\circ} \mathrm{C}$ for 1 min. These mixes were homogenized by a Lab homogenizer (Microfluidics, M-110P) at 25000 rpm while being hot. Then, they were allowed to cool down to $50{ }^{\circ} \mathrm{C}$. After homogenization, the untreated-control mix was further cooled to $4{ }^{\circ} \mathrm{C}$ and left for aging for $24 \mathrm{~h}$. The batches $A$ and $B$ were treated with MTG. Before being added to the mixture, the calculated amount of enzyme was stirred into $50 \mathrm{~mL}$ of the mix. The enzyme reaction was carried out at $50^{\circ} \mathrm{C}$ for 30 min and the deactivation was carried out by a short heat treatment $\left(80{ }^{\circ} \mathrm{C}\right.$ for 1 min) (Lorenzen et al., 2002). The batches $C$ and D were heated to $50{ }^{\circ} \mathrm{C}$ and treated with MTG for 30 min. Then the batches were pasteurized at $85^{\circ} \mathrm{C}$ for $1 \mathrm{~min}$. All mixes were cooled to $4{ }^{\circ} \mathrm{C}$ for aging for $24 \mathrm{~h}$. The ice-cream was produced by using a vertical freezing machine of $6 \mathrm{~kg}$ capacity (Uğur, Nazilli, Turkey). The partially frozen mix was packaged in 50, 100 and $200 \mathrm{~mL}$ cups and stored at $-18^{\circ} \mathrm{C}$. The experiment was conducted in duplicate.

Physical, chemical and sensory analyses were carried out 1 day after production.

\section{Chemical analysis}

The $\mathrm{pH}$ of milk and ice-cream was measured using a digital pH-meter (Thermo Scientific Orion 4 Star) and titratable acidity was measured by titrating $10 \mathrm{~g}$ of the sample with $0.1 \mathrm{~N} \mathrm{NaOH}$ using phenolphthalein indicator (T.S.E., 1994). The dry matter of ice-cream was determined by drying samples at $100 \pm 1{ }^{\circ} \mathrm{C}$ for $3.5 \mathrm{~h}$ using an air oven (Kendro Laboratory Products UT12, $250^{\circ} \mathrm{C}$ ) (T.S.E., 1994). The fat content of ice cream was determined by the Gerber method (T.S.E., 1994). The protein content of ice cream was estimated from the crude 
nitrogen content of the samples determined by the Dumas method (AOAC, 2003).

\section{Physical measurements}

The overrun of the final product was determined using the formula below (Akın et al., 2007):

First dripping and complete melting times were

Overrun $=\frac{\begin{array}{l}\text { the weight of equal volume of } \\ \text { ice-cream }\end{array}}{\begin{array}{l}\text { the weight of unit mix - the } \\ \text { weight of equal volume of } \\ \text { ice-cream }\end{array}} \times 100$

measured according to method proposed by Güven and Karaca (2002). $25 \mathrm{~g}$ of tempered samples were left to melt (at room temperature, $20^{\circ} \mathrm{C}$ ) on a $0.2 \mathrm{~cm}$ wire mesh screen above a beaker. First dripping and complete melting times of samples were determined as seconds.

The viscosity of ice-cream samples were determined at $4{ }^{\circ} \mathrm{C}$ using a digital Brookfield Viscometer, Model DV-II (Brookfield Engineering Laboratories, Stoughton, MA, USA). A cylindrical spindle (no.4) was used for the determination of viscosity. The rotation rate was $20 \mathrm{rpm}$ and readings were recorded after 10 secs. (Akin, 2005).

\section{Microstructure}

Samples of ice cream (0.3 g) were excised at approximately $1 \mathrm{~cm}$ below the surface and mixed with $0.3 \mathrm{~g}$ of $3 \%$ aqueous agar solution (Oxoid code L13) at $45^{\circ} \mathrm{C}$ and the mixtures were solidified by cooling at $20{ }^{\circ} \mathrm{C}$ (Tamime et al., 1995). The gelled samples were cut into $1 \mathrm{~mm}$ cubes and fixed in a $2 \%$ glutaraldehyde solution in phosphate buffer (0.1 $\mathrm{m}, \mathrm{pH}$ 7.2) as primary fixative to crosslink proteins (Kalab et. al., 1995) at room temperature for $2 \mathrm{~h}$, followed by $24 \mathrm{~h}$ at $4{ }^{\circ} \mathrm{C}$ (McManus et al., 1993). The fixed samples were washed with phosphate buffer and postfixed in a $1 \%$ osmium tetraoxide solution in phosphate buffer for $2 \mathrm{~h}$ for stabilizing unsaturated lipids (Kalab et al., 1995). The postfixed samples were washed with phosphate buffer and dehydrated in agraded ethanol series (30\%, $50 \%, 70 \%, 80 \%$ and $90 \%$ respectively, $1 \mathrm{~h}$ in each), Afterwards, they were also dehydrated in ab- solute ethanol for $24 \mathrm{~h}$ and critical point dried with a EMS 850 CriticalPoint Dryer (TEM-SEM Kim. Mad. ve Lab. Cihz., Turkey) in carbondioxide. Dry sections were fractured with a blade and fragments were mounted on aluminum SEM stubs (Modler and Kalab, 1983), and coated with vacuum gold via an EMS 550X (TEM-SEM Kim. Mad. ve Lab. Cihz., Turkey). The microstructure of the ice cream was examined with a high vacuum scanning electron microscope ZEIS EVO 50 (Carl Zeiss Microscopy, Germany) at $15-20 \mathrm{kV}$, with a magnification of $1.50 \mathrm{~K}$.

\section{Sensory assessment}

The samples were subjected to sensory evaluation by untrained ten panelists using a 10 points hedonic scale in order to evaluate coldness, firmness, viscosity, smoothness, color and appearance, mouth coating, flavour and taste, and general acceptability $(1$ = strongly unacceptable, 10 = very good) as described by Aime et al. (2001). The panel of assessors was an external panel of non-smokers who were very familiar with dairy products and were checked on the basis of sensory acuity and consistency.

\section{Statistical analysis}

The experiment was designed according to a $(3 \times 2 \times 2)$ factorial design. All statistical analyses were carried out using the SPSS statistical software program (version 5.0). Statistically different groups were determined by the Duncan's Multiple Range test (Bek and Efe, 1995).

\section{Results and discussion}

\section{Physico-chemical properties}

The gross chemical composition of ice-cream samples is given in Table 2. The effect of MTG enzyme with or without stabilizer and adding stage of it on dry matter, $\mathrm{pH}$ and titratable acidity was insignificant ( $p>0.05$ ). Rossa et al. (2012), Aloglu and Oner (2013), Romeih et al. (2014) and Kafshgari et al. (2014) also reported that addition of MTG did not affect the chemical composition such as total 
solids, fat, protein, lactose, and acidity of ice cream or yoghurt. Hovewer, Rahmani et al. (2014) report- ed that the addition of MTG enzyme raised the protein content of prebiotic low fat ice cream.

TABLE 2. Gross chemical composition of ice-cream samples

\begin{tabular}{l|l|l|l|l|l|l}
\hline $\begin{array}{l}\text { MTG } \\
\text { treatment } \\
\text { stage }\end{array}$ & Sample & $\mathrm{pH}$ & $\begin{array}{l}\text { Titratable } \\
\text { acidity } \\
(\% \text { lactic acid) }\end{array}$ & $\begin{array}{l}\text { Dry matter } \\
(\%)\end{array}$ & Fat (\%) & Protein (\%) \\
\hline $\begin{array}{l}\text { After heat } \\
\text { treatment }\end{array}$ & $\mathrm{A}$ & $6.57 \pm 0.000^{\mathrm{b} 2}$ & $0.21 \pm 0.001^{\mathrm{a} 1}$ & $32.52 \pm 0.148^{\mathrm{c} 3}$ & $4.00 \pm 0.000^{\mathrm{a} 1}$ & $4.08 \pm 0.170^{\mathrm{a} 1}$ \\
\cline { 2 - 7 } & $\mathrm{B}$ & $6.60 \pm 0.000^{\mathrm{a} 1}$ & $0.20 \pm 0.003^{\mathrm{a} 1}$ & $32.86 \pm 0.113^{\mathrm{b} 2}$ & $4.05 \pm 0.000^{\mathrm{a} 1}$ & $4.04 \pm 0.035^{\mathrm{a} 1}$ \\
\hline $\begin{array}{l}\text { Before heat } \\
\text { treatment }\end{array}$ & $\mathrm{C}$ & $6.57 \pm 0.007^{\mathrm{b} 2}$ & $0.21 \pm 0.006^{\mathrm{a} 1}$ & $32.58 \pm 0.071^{\mathrm{c} 3}$ & $4.03 \pm 0.035^{\mathrm{a} 1}$ & $4.06 \pm 0.106^{\mathrm{a} 1}$ \\
\cline { 2 - 7 } & $\mathrm{D}$ & $6.60 \pm 0.007^{\mathrm{a} 1}$ & $0.20 \pm 0.004^{\mathrm{a} 1}$ & $32.88 \pm 0.057^{\mathrm{b} 2}$ & $4.05 \pm 0.071^{\mathrm{a} 1}$ & $3.99 \pm 0.325^{\mathrm{a} 1}$ \\
\hline Control & $\mathrm{E}$ & $6.62 \pm 0.007^{\mathrm{a} 1}$ & $0.19 \pm 0.004^{\mathrm{a} 2}$ & $33.21 \pm 0.099^{\mathrm{a} 1}$ & $4.08 \pm 0.035^{\mathrm{a} 1}$ & $3.91 \pm 0.035^{\mathrm{a} 1}$ \\
\hline
\end{tabular}

${ }^{*} \mathrm{~A}: 1 \mathrm{U} / \mathrm{g}$ protein, B:0.5 U/g protein, C: $1 \mathrm{U} / \mathrm{g}$ protein, D:0.5 U/g protein, E: control

a, b, c Means in the same column followed by different letters and numbers were significantly different according to MTG level and treatment stage, respectively $(p<0.01)$

TABLE 3. Physical properties of ice-cream samples

\begin{tabular}{l|l|l|l|l|l}
\hline $\begin{array}{l}\text { MTG } \\
\text { treatment } \\
\text { stage }\end{array}$ & Sample* & Viscosity (cP) & Overrun (\%) & $\begin{array}{l}\text { First dripping } \\
\text { time (secs) }\end{array}$ & $\begin{array}{l}\text { Complete melting } \\
\text { time (secs) }\end{array}$ \\
\hline $\begin{array}{l}\text { After heat } \\
\text { treatment }\end{array}$ & A & $890 \pm 4.243^{\mathrm{d} 4}$ & $23.12 \pm 0.332^{\mathrm{d} 4}$ & $765.50 \pm 14.849^{\mathrm{c} 4}$ & $2297 \pm 32.527^{\mathrm{c} 4}$ \\
\cline { 2 - 6 } & $\mathrm{B}$ & $4060 \pm 28.284^{\mathrm{b} 2}$ & $32.88 \pm 0.269^{\mathrm{a} 1}$ & $1229.50 \pm 54.447^{\mathrm{a} 1}$ & $3413.50 \pm 61.518^{\mathrm{a} 1}$ \\
\hline $\begin{array}{l}\text { Before heat } \\
\text { treatment }\end{array}$ & $\mathrm{C}$ & $573.50 \pm 37.477^{\mathrm{e} 5}$ & $21.95 \pm 0.332^{\mathrm{e} 5}$ & $715.50 \pm 30.406^{\mathrm{c} 5}$ & $2126 \pm 53.740^{\mathrm{d} 5}$ \\
\cline { 2 - 6 } & $\mathrm{D}$ & $2823 \pm 24.042^{\mathrm{c} 3}$ & $26.83 \pm 0.573^{\mathrm{c} 3}$ & $1059 \pm 12.728^{\mathrm{b} 3}$ & $3072 \pm 33.941^{\mathrm{b3}}$ \\
\hline Control & E & $5840 \pm 123.037^{\mathrm{a} 1}$ & $30.83 \pm 0.544^{\mathrm{b} 2}$ & $1107.50 \pm 45.962^{\mathrm{b} 2}$ & $3166.50 \pm 54.447^{\mathrm{b} 2}$ \\
\hline
\end{tabular}

${ }^{*} \mathrm{~A}: 1 \mathrm{U} / \mathrm{g}$ protein, B:0.5U/g protein, C: $1 \mathrm{U} / \mathrm{g}$ protein, D:0.5U/g protein, E: control

a, b, c Means in the same column followed by different letters and numbers were significantly different according to MTG level and treatment stage, respectively $(p<0.01)$

Physical properties of ice-cream samples are shown in Table 3. Sample B has the highest overrun value. Overrun values of ice creams without stabilizers are lower in comparison to the other samples. For a fact, stabilizers partially improve the product aeration. Using MTG enzyme alone as a stabilizer caused lower overrun values in the samples, but when MTG enzyme was used with stabilizers, overrun values increased from 21.95 to $32.88 \%$ ( $p<0.01)$. The enzyme cross-linking of milk serum proteins and proteins of fat globules would have enhanced the cohesion properties of air cells lamella and the adherence of the adsorbed film of fat globules (Metwally et al., 2007). This action resulted in a high overrun with stable foam in low stabilizer samples B and D. Increasing overrun of ice cream treated by MTG enzyme was also reported by several researchers (Metwally et al., 2007; Rossa et al., 2012; Rahmani et al., 2014; Kafshgari et al., 2014). Similarly, the addition stage of the MTG enzyme had a significant effect on overrun values of the ice cream samples $(p<0.01)$. The overrun values of samples treated with MTG enzymes after pasteurization were higher compared to the samples treated with MTG enzymes before pasteurization. This can be related to the stabilization of the foam emulsion system by MTG enzyme which makes crosslinks of inter-or intra-molecular $\varepsilon$-( $\gamma$-glutamine)-lysine isopeptide bonds and leads to keep the air cells into the three-dimensional net- 
work structure (Gharibzahedi et al., 2018a). Thus, the formation of casein polymers involving air bubbles increases volume and air bubble stabilization as in the sample B. Similar results were found in low-fat ice cream by Rossa et al. (2012) and Metwally et al. (2007).

In terms of the viscosity, the control sample was the highest $(p<0.01)$. On the contrary, Metwally et al. (2007) and Rossa et al. (2012) reported that the samples containing TG enzyme had higher viscosity compared to control samples (without TG enzyme). This could be explained by a lack of stabilizer or the half amount of stabilizer in MTG enzyme treated to ice cream when compared to the control. Stabilizers increase the water binding capacity, hence do not allow the water to flow. Samples A and C without added stabilizer had the lowest viscosity value. Also the samples $B$ and $D$ contained about half the amount of stabilizer in comparison to the control (E) sample. The samples contained a regular stabilizer as mentioned in the studies above. The addition of MTG enzyme with stabilizer caused a significant increase in the viscosity $(p<0.01)$, probably due to the ability of MTG enzyme to form high-molecular-weight polymers from monomers of proteins, conferring greater resistance to flow and the effects of the stabilizer. Garibzahedi et al. (2018a) reported that the polymerization of milk proteins through crosslinking reactions caused a notable increase of the water binding capacity by the formed high-molecular weight matrix, and so this bioengineered protein structure can greatly allow more resistance to flow. Similarly, in this study, viscosity values in the samples ( $B$ and $D$ ) treated with MTG enzyme after pasteurization were higher than the samples treated with MTG enzyme before pasteurization $(p<0.01)$. This can be explained by the formation of cross-linking with denaturated whey protein and caseins (O'Sullivan et al., 2002).

First dripping and complete melting times of ice creams without stabilizers have shorter than other samples. The first dripping times and complete melting times prolonged when MTG enzymes were used with stabilizers $(p<0.01)$. This could be related to the polymerization of milk proteins by the action of TG enzyme (Rossa et al., 2011) which led to an increase in the stability of ice cream, especially when the amount of fat in the formulation was reduced (Rossa et al., 2012). Furthermore, stabilizers provide greater resistance to the flow of the liquid phase resulting in slower melting. Our results indicated that the addition stage of the MTG enzyme had also a significant effect on the firstdripping and complete melting times $(p<0.01)$. Sample B had the longest first dripping and complete melting times. Sharma et al. (2001) reported that a heating step can cause a noticeable increase in the crosslinking of proteins. This fact could be related to the kinetic improvement of protein reorganization induced by MTG enzyme at high temperatures. In heated milk, the MTG enzyme keeps more whey proteins into the matrix with reduced syneresis by changing the physical features of protein gels with low porosity (Gharibzahedi et al., 2018a). According to Cruz et al. (2009), the melting time of ice cream is related to its stability after overrun. Likewise, in the present study, stability of the samples (A and B) treated with MTG enzyme after pasteurization was better than in the samples (C and D) treated with MTG enzyme before pasteurization.

TABLE 4. Sensory characteristics of ice cream samples

\begin{tabular}{l|l|l|l|l|l|l|l|l|l}
\hline $\begin{array}{l}\text { MTG } \\
\text { treatment } \\
\text { stage }\end{array}$ & Sample* & Coldness & Firmness & Viscosity & Smoothness & $\begin{array}{l}\text { Mouth } \\
\text { coating }\end{array}$ & $\begin{array}{l}\text { Color and } \\
\text { appearance }\end{array}$ & $\begin{array}{l}\text { Taste and } \\
\text { smell }\end{array}$ & $\begin{array}{l}\text { General } \\
\text { acceptability }\end{array}$ \\
\hline $\begin{array}{l}\text { After heat } \\
\text { treatment }\end{array}$ & A & $6.94 \pm 0.177^{\mathrm{b} 2}$ & $4.63 \pm 0.276^{\mathrm{c} 3}$ & $4.88 \pm 0.233^{\mathrm{c} 3}$ & $4.20 \pm 0.247^{\mathrm{c} 3}$ & $4.00 \pm 0.163^{c 3}$ & $7.15 \pm 0.113^{\mathrm{c} 3}$ & $5.87 \pm 0.219^{\mathrm{c} 3}$ & $5.12 \pm 0.247^{\mathrm{c} 3}$ \\
\cline { 2 - 10 } $\begin{array}{l}\text { Before heat } \\
\text { treatment }\end{array}$ & $\mathrm{C}$ & $5.19 \pm 0.219^{\mathrm{d} 4}$ & $8.07 \pm 0.156^{\mathrm{a} 1}$ & $8.45 \pm 0.085^{\mathrm{a} 1}$ & $8.44 \pm 0.134^{\mathrm{a} 1}$ & $8.24 \pm 0.014^{\mathrm{a} 1}$ & $9.13 \pm 0.099^{\mathrm{a} 1}$ & $8.70 \pm 0.297^{\mathrm{a} 1}$ & $8.26 \pm 0.099^{\mathrm{a} 1}$ \\
\hline & $\mathrm{D}$ & $6.60 \pm 0.170^{\mathrm{a} 1}$ & $3.89 \pm 0.255^{\mathrm{d} 4}$ & $4.55 \pm 0.191^{\mathrm{c} 3}$ & $3.84 \pm 0.184^{\mathrm{c} 4}$ & $3.82 \pm 0.148^{\mathrm{c} 3}$ & $7.08 \pm 0.191^{\mathrm{c} 3}$ & $4.82 \pm 0.226^{\mathrm{d4}}$ & $4.55 \pm 0.106^{\mathrm{d} 4}$ \\
\hline Control & $\mathrm{E}$ & $5.07 \pm 0.226^{\mathrm{d} 4}$ & $8.14 \pm 0.198^{\mathrm{a} 1}$ & $8.57 \pm 0.134^{\mathrm{a} 1}$ & $8.24 \pm 0.276^{\mathrm{a} 1}$ & $8.29 \pm 0.177^{\mathrm{a} 1}$ & $9.09 \pm 0.205^{\mathrm{a} 1}$ & $8.69 \pm 0.205^{\mathrm{a} 1}$ & $8.23 \pm 0.170^{\mathrm{a} 1}$ \\
\hline
\end{tabular}

${ }^{*} \mathrm{~A}: 1 \mathrm{U} / \mathrm{g}$ protein, B:0.5U/g protein, C: $1 \mathrm{U} / \mathrm{g}$ protein, D:0.5U/g protein, E: control

$\mathrm{a}, \mathrm{b}, \mathrm{c}$ Means in the same column followed by different letters and numbers were significantly different according to MTG level and treatment stage, respectively $(p<0.01)$ 


\section{Sensory evaluations}

Adding MTG enzyme with or without the stabilizer and the addition stage significantly $(p<0.01)$ affected the tested sensory characteristics (Table 4) of ice cream samples, as well. For instance, Sample $C$ had the highest coldness value and was followed by samples $A, D, B$, and $E$, respectively. This result could be related to MTG enzyme and stabilizer amount of ice cream samples. Whilst sample A and C had MTG enzyme without stabilizer, sample $B$ and D had MTG enzyme with stabilizer, which was half of the stabilizer of the control sample (E). Coldness is related to large ice particles. When the water content increases, larger ice particles are formed and the sensation of coldness is intensified (Aime et al., 2001). MTG enzyme causes an increase in the water content of food. In addition, stabilizers can bind water and thus cause small ice crystals to ocur in ice cream. On the other hand, after control, sample $B$ and $D$ had the highest firmness and viscosity scores. Because of crosslinking between milk serum proteins and fat globules in ice cream, which is formed by MTG enzyme, a higher cohesiveness effect was obtained (Sharma et al., 2001). Therefore, these ice cream samples had a firmer and more viscous structure than other samples. Rossa et al. (2012) reported that the addition of the MTC enzyme increased the hardness of ice creams. In our study, Sample B had the highest smoothness and mouth coating scores. The use of MTG with stabilizer resulted in a higher cohesion effect, more air entrapment in the ice cream, a smoother structure and slower melting of ice creams. The use of MTG enzymes with stabilizers also affected color and appearance and taste and smell scores of ice cream samples in a positive way. Kirmaci (2005) reported that the MTG enzyme improved physical and rheological properties of the product without affecting the taste and odor characteristics. But, in our study, the highest general acceptability score was recorded for sample B. Thus, the addition of MTG enzyme after heat treatment improved sensory characteristics of ice cream samples, due to an increase in the crosslinking of proteins. Gharibzahedi et al. (2018a) reported that high overall acceptability of ice cream formulations, modified via MTG enzyme crosslinking, could be resulted from improving the structural stability and rheolog- ical behavior of the frozen ice cream foams with a reduction in ice crystals formation. As a result, samples A and B had lower coldness and higher firmness, viscosity, smoothness, mouth coating, color and appearance, taste and smell and general acceptability scores than Samples C and D.

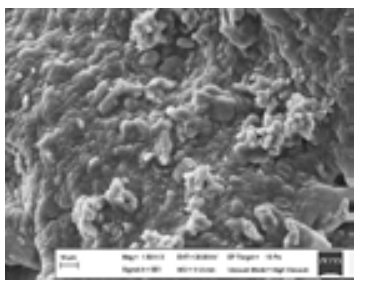

A)

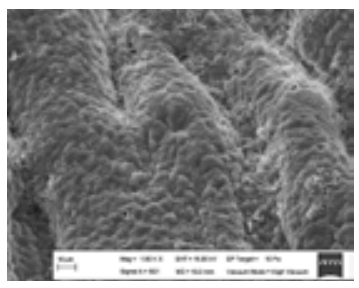

B)

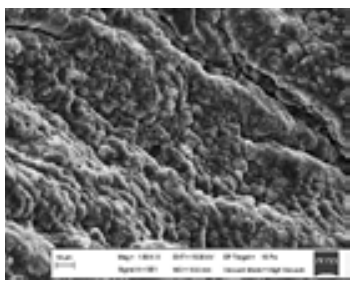

c)

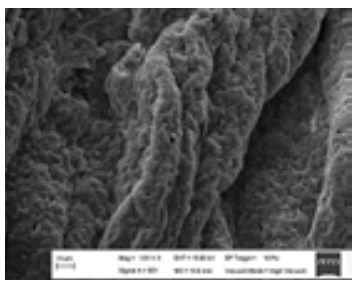

D)

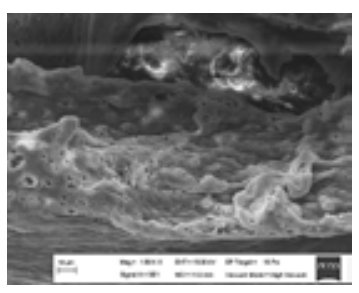

E)

FIGURE 1. Microstructure of ice cream samples: (a) Sample A: $0.7 \mathrm{U} / g$ protein MTG was added after heat treatment, b) Sample B: $0.35 \mathrm{U} / g$ protein MTG was added after heat treatment, c) Sample C: $0.7 \mathrm{U} / g$ protein MTG was added before heat treatment, d) Sample D: $0.35 \mathrm{U} / \mathrm{g}$ protein MTG was added before heat treatment, e) Control (MTG not added)

\section{Microstructures of ice cream samples}

Microstructure of ice cream samples are shown in Figures 1-5. Therefrom it could be observed that there were more air bubbles in the control sample and the structure was hollower compared to MTG enzyme treated ice creams. The more MTC enzyme was added, the less compact structure was obtained in the MTG treated samples due to a lack of stabilizers (Fig 1-4). Actually, it is expected that higher amount of MG would cause a more compact structure because of more intense cross-linking between the proteins. But, we determined that the addition of stabilizer with MTG enzyme improved 
the structure of ice cream. This can be explained by the water binding capacity of the stabilizer. Gharibzahedi et al. (2018a) reported that the viscosity could further be intensified via the interaction of MTG enzyme with other carbohydrates such as inulin contained in the ice cream matrix. On the other hand, MTG treatment after heating resulted in a more compact structure than MTG treatment before heating. This could be related to an increase in denatured proteins caused by heating. Accordingly, the kinetic improvement of proteins was reorganized and MTG enzyme kept more whey proteins into the matrix (Gharibzahedi et al., 2018a). As a result, syneresis reduced and structure became more compact (Fig 1-2 and 3-4).

\section{Conclusions}

According to the results, the stabilizer amount can be reduced halved by using MTG enzyme in the fat-reduced ice cream. Results also showed that the application of MTG enzyme with stabilizer obviously improved the sensory and physical properties of ice cream samples. However, application of MTG enzyme without stabilizer was not suitable in the production of fat-reduced ice cream. Also, it has been determined that the addition of MTG after heat treatment was more appropriate in terms of physical and sensory properties of ice cream samples. Consequently, the MTG enzyme can be used to reduce the amount of stabilizer in the fat-reduced ice cream production after heat treatment.

\section{Acknowledgments}

This study was formed by the MSC thesis of Mrs. Busra Goncu and financially supported by the Research Fund of Harran University (Project No: 11100).

The authors thank the Actica, Ajinomoto Co Inc. (Japan) for the enzyme gift

\section{Dizajn industrijskog protokola razvoja nove recepture sladoleda smanjenog udjela masti uz uporabu mikrobne transglutaminaze kao zamjene za stabilizatore}

\section{Sažetak}

U ovoj studiji je istražena mogućnost zamjene stabilizatora mikrobnom transglutaminazom (MTG) u proizvodnji sladoleda sa smanjenim udjelom masti. Pri tom je također ispitivan utjecaj vremena dodavanja MTG (prije ili nakon toplinske obrade) na svojstva sladoleda. Proizvedeno je 5 različitih uzoraka sladoleda: A i C s 1 jedinicom MTG/g proteina, bez stabilizatora; B i D s 0,5 jedinica MTG/g proteina i 0,35 \% stabilizatora, (smjesa karagenana (E 407), guar gume (E 412), ksantan gume (E 415) i natrijevog alginata (E 401)) i E (kontrola) s 0,7 \% stabilizatora. MTG je dodavan uzorcima A i B nakon, a uzrocima C i D prije toplinske obrade. Svim uzorcima su određivani porast volumena, viskoznost, svojstva topljenja, pH, titracijska kiselost, suha tvar, udio masti i proteina, senzorska svojstva i mikrostruktura. Sukladno dobivenim rezultatima količina i vrijeme dodatka MTG značajno su utjecali na porast volumena, topljenje, viskoznost, osjet hladnoće, čvrstoću, glatkoću, punoću okusa u ustima, boju, izgled, okus, miris te na mikrostrukturu sladoleda $(p<0,01)$. Također se pokazalo da se MTG može koristiti skupa sa stabilizatorima, no u tom slučaju se treba dodavati nakon toplinske obrade sladoledne smjese. Zaključno, uzorak B se prema rezultatima senzorske analize pokazao najsličnijim kontrolnom uzorku.

\section{Ključne riječi: sladoled smanjenog udjela masti, transglutaminaza, stabilnost, kvaliteta, mikrostruktura}


1. Adapa, S., Dingeldein, H., Schmidt, K.A., Herald, T.J. (2000): Rheological properties of ice cream mixes and frozen ice creams containing fat and fat replacers. Journal of Dairy Science 83 (10), 2224-2229.

https://doi.org/10.3168/jds.s0022-0302(00)75106-x

2. Aime, D.B., Arntfield, S.D., Malcomson, L.J., Rayland, D. (2001): Textural analysis of fat reduced vanilla ice cream products. Food Research International 34, 237-246. https://doi.org/10.1016/s0963-9969(00)00160-5

3. Akın, M.S. (2005): Effects of inulin and different sugar levels on viability of probiotic bacteria and the physical and sensory characteristics of probiotic fermented ice-cream. Milchwissenschaft 60 (3), 297-301.

4. Akin, M.B., Akin, M.S., Kirmaci, Z. (2007): Effects of inulin and sugar levels on the viability of yogurt and probiotic bacteria and the physical and sensory characteristics in probiotic ice cream. Food Chemistry 104 (1), 93-99. https://doi.org/10.1016/j.foodchem.2006.11.030

5. Aloğlu, H.S., Oner, Z. (2013): The effect of treating goat's milk with transglutaminase on chemical, structural, and sensory properties of labneh. Small Ruminant Research, 109, 31-3. https://doi.org/10.1016/j.smallrumres.2012.10.005

6. AOAC (2003): AOAC (Association of Official Analytical Chemists). Qualitative Tests for Protein: Dumas Method (7.017). In: Official Methods of Analysis. Washington, DC, USA.

7. Bek, Y., Efe, E. (1995): Araştırma ve Deneme Metotları. Ç.Ü. Ziraat Fakültesi. Ders Notları No:71, Adana.

8. Benjamins, J., Vingerhoeds, M.H., Zoet, F.D., Hoog, E.H.A., van Aken, G.A. (2009): Partial coalescence as a tool to control sensory perception of emulsions. Food Hydrocolloids 23 (1), 102-115 https://doi.org/10.1016/j.foodhyd.2007.11.017

9. Cottrell, J.I.L., Pass, G. Phillips, G.O. (1980): The effect of stabilizers on the viscosity of an ice cream mix. Journal of Food Science and Agriculture 31, 1066-1070.

10. Cruz, A.G., Antunes, A.E.C., Sousa, A.L.O.P., Faria, J.A.F., Saad, S.M.I. (2009): Ice-cream as a probiotic food carrier. Food Research International 42 (9), 1233-1239. https://doi.org/10.1016/j.foodres.2009.03.020

11. De Goes-Favoni, S.P., Bueno, F.R. (2014): Microbial transglutaminase: general characteristics and performance in food processing technology. Food Biotechnology 28 (1), $1-24$. https://doi.org/10.1080/08905436.2013.870076

12. El-Nagar, G., Clowes, G., Tudorica, C. M., Kuri, V. (2002): Rheological quality and stability of yog-icecream with added inulin. International Journal of Dairy Technology 55, 89-93. https://doi.org/10.1046/j.1471-0307.2002.00042.x

13. Faergemand, M., Murray, B.S., Dickinson, E., Quvist, K.B. (1999): Transglutaminase: effect on instrumental and sensory texture of set style yoghurt. Milcwissenschaft 54, 563-566.

14. FDA (2010): FDA - Food and Drug Administration Numerical listing of GRAS notices<http://www. accessdata.fda.gov/scripts/fcn/fcnNavigation. cfm?filter=transglutaminase \&sortColumn $=\& r p t=$ grasListing $>$ Accessed 25.03.10.
15. Gharibzahedi, S.M.T., Koubaa, M., Barba, F.J., Greiner, R., George, S., Roohinejad, S. (2018a): Recent advances in the application of microbial transglutaminase crosslinking in cheese and ice cream products: A review. International Journal of Biological Macromolecules, 107, 2364-2374. https://doi.org/10.1111/1541-4337.12324

16. Gharibzahedi, S.M.T., George, S., Greiner, R., Estevinho, B.N., Fernández, F., José, M., Roohinejad, S. (2018b): New trends in the microencapsulation of functional fatty acidrich oils using transglutaminase catalyzed crosslinking. Comprehensive Reviews in Food Science and Food Safety 17, 1-16. https://doi.org/10.1111/1541-4337.12324

17. Gharibzahedi, S.M.T., Chronakis, I.S. (2018): Crosslinking of milk proteins by microbial transglutaminase: utilization in functional yogurt products. Food Chemistry 245, 620-632. https://doi.org/10.1016/j.foodchem.2017.10.138

18. Goff, H.D. (2002): Formation and stabilization of structure in ice-cream and related products. Current Opinion in Colloid and Interface Science 7 (5-6), 432-437. https://doi.org/10.1016/s1359-0294(02)00076-6

19. Gonzalez-Tomas, L., Bayarri, S., Taylor, A.J., Costell, E. (2008): Rheology, flavour release and perception of low-fat dairy desserts. International Dairy Journal 18 (8), 858-866. https://doi.org/10.1016/j.idairyj.2007.09.010

20. Granger, C., Legerb, A., Barey, P., Langendorff, V., Cansell, M. (2005): Influence of formulation on the structural networks in ice cream. International Dairy Journal 15 (3), 255-262. https://doi.org/10.1016/j.idairyj.2004.07.009

21. Güven, M., Karaca, O.B. (2002): The effects of varying sugar content and fruit concentration on the physical properties of vanilla and fruit ice-cream-type frozen yogurts. International Journal of Dairy Technology 55, 27-31. https://doi.org/10.1046/j.1471-0307.2002.00034.x

22. Hinz, K., Huppertz, T., Kelly, A.L. (2012): Susceptibility of the individual caseins in reconstituted skim milk to crosslinking by transglutaminase: influence of temperature, $\mathrm{pH}$ and mineral equilibria. Journal of Dairy Research 79 (4), 414-421. https://doi.org/10.1017/s0022029912000374

23. Jooyandeh,H., Danesh, E., Goudarzi, M.(2017): Effect of microbial transglutaminase on physical, rheological, textural and sensory properties of light ice cream. Iranian Food Science and Technology Research Journal 13, 469-479.

24. Kalab, M., Allan-Wojtas, P., Miller, S.S. (1995): Microscopy and other imaging techniques in food structure analysis. Trends in Food Science and Technology 6, 177-186. https://doi.org/10.1016/s0924-2244(00)89052-4

25. Kafshgari, S.F., Alami, M., Khomeiri, M., Motamedzadegan, A., Mohammad, J.A.M. (2014): Optimization of low-fat ice cream formulation using microbial transglutaminase and protein-based fat replacers, Journal of Research Innovative Food Science and Technology 3, 227-244.

26. Kafshgari, S.F., Alami, M., Khomeiri, M., Motamedzadegan, A. (2017): The effect of microbial transglutaminase and protein-based fat replacers on the physical properties of low-fat ice cream, Iranian Journal of Food Science and Technology 14 191-200. 
27. Kasprzyk, I., Markowska J., Polak, E. (2016): Effect of microbial transglutaminase on ice cream heat resistance properties - a short report. Poland Journal of Food and Nutrition Science 66 (3), 227-231. https://doi.org/10.1515/pjfns-2015-0037

28. Kirmaci, H.A. (2005): Yağsız Yoğurtlarda Transglutaminaz Enzimi Kullanımının Yoğurdun Tekstürel Özellikleri Üzerine Etkileri. Harran Üniversitesi Fen Bilimleri Enstitüsü Yüksek Lisans Tezi (Ms thesis), Sanliurfa, Turkey. https://doi.org/10.9775/kvfd.2015.13833

29. Kieliszek, M., Misiewicz, A. (2014): Microbial transglutaminase and its application in the food industry a review. Folia Microbiologica 59 (3), 241-250. https://doi.org/10.1007/s12223-013-0287-x

30. Koxholt, M.M.R., Eisenmann, B., \& Hinrichs, J. (2001). Effect of the fat globule sizes on the meltdown of ice cream. Journal of Dairy Science 84 (1), 31-37. https://doi.org/10.3168/jds.s0022-0302(01)74448-7

31. Lal, S.N.D., O’Connor, C.J., Eyres, L. (2006): Application of emulsifiers/stabilizers in dairy products of high rheology. Advances in Colloid and Interface Science, 123-126, 433437. https://doi.org/10.1016/j.cis.2006.05.009

32. Lorenzen, P.C., Neve, H., Mautner, A., Schlimme, E. (2002): Effect of enzymatic cross-linking of milk proteins on functional properties of set-style yoghurt. International Dairy Journal 55 (3), 152-157. https://doi.org/10.1046/j.1471-0307.2002.00065.x

33. McManus W.R., McMahon D.J., Oberg, C.J. (1993): Highresolution scanning electron microscopy of milk products: a new sample preparation procedure. Food Structure 12 (4), 475-482.

34. Metwally, A.M.M.E. (2007): Effect of enzymatic crosslinking of milkproteins on properties of icecream with different composition. International Journal of Food Science and Technology 42, 939-947.

35. O'Sullivan, M.M., Kelly, A.L., Fox, P.F. (2002): Effect of transglutaminase on the heat stability of milk: a possible mechanism. Journal of DairyScience 85, 1-7.

36. Rahmani F., Fadaei, V., Tabari, M. (2014): The effect of enzyme transglutaminase on some physicochemical properties of prebiotic low-fat traditional ice cream. International Journal of Biology and Biotechnology 11, 555561.
37. Romeih, E.A., Abdel-Hamid, M., Awad, A.A. (2014). The addition of buttermilk powder and transglutaminase improves textural and organoleptic properties of fat-free buffalo yogurt. Dairy Science Technology 94, 297-309. https://doi.org/10.1007/s13594-014-0163-8

38. Romeih, E., Walker, G. (2017): Recent advances on microbial transglutaminase and dairy application. Trends in Food Science and Technology 62, 133-140. https://doi.org/10.1016/j.tifs.2017.02.015

39. Rossa, N.R., Burin, V.M., Bordignon-Luiz, M.T. (2012): Effect of microbial transglutaminase on functional and rheological properties of icecream with different fat contents. LWT - Food Science and Technology 48, 224-230. https://doi.org/10.1016/j.lwt.2012.03.017

40. Rossa, N.R., Sá, E.M.F., Burin, V.M. Bordignon-Luiz, M.T. (2011): Optimization of microbial transglutaminase activity in icecream using response surface methodology. LWT -

Food Science and Technology 44, 29-34. https://doi.org/10.1016/j.lwt.2010.06.013

41. Sharma, R., Lorenzen, P.C., Qvist, K.B. (2001): Influence of transglutaminase treatment of skim milk on the formation of $\varepsilon$-( $\gamma$-glutamyl) lysine and the susceptibility of individual proteins towards crosslinking. International Dairy Journal 11, 785-793. https://doi.org/10.1016/s0958-6946(01)00096-6

42. Soleymanpuori, R., Madadlou A.,Zeynali F., Khosrowshahi, A. (2014): Enzymatic cross-linking of soy proteins within nonfat set yogurt gel. Journal of Dairy Research 81 (3),378-84. https://doi.org/10.1017/s0022029914000302

43. Sanli, T., Şenel, E., Sezgin, E., Benli, M. (2014): The effects of using transglutaminase, exopolysaccharide-producing starter culture and milk powder on the physicochemical, sensory and texture properties of low-fat set yoghurt. International Journal of Dairy Technology 67 (2), 237-245. https://doi.org/10.1111/1471-0307.12127

44. T.S.E. (1994): Raw Milk Standard. T.S. 1330. Turkish Standardization Institute, Ankara.

45. Tamime, A.Y., Kalab, M., Muir, D.D., Barrantes, E. (1995): The microstructure of set-style, natural yogurt made by substituting microparticulate whey protein for milk fat. International Journal of Dairy Technology 48, 107-111. https://doi.org/10.1111/j.1471-0307.1995.tb02478.x

46. Vega, C., Goff, H.D. (2005): Phase separation in soft-serve ice cream mixes: rheology and microstructure. International Dairy Journal 15 (3), 249-254. https://doi.org/10.1016/j.idairyj.2004.07.007 